\title{
Biogeochemical processes at soil-root interface
}

\author{
A. Violante ${ }^{1 *}$ and A.G. Caporale ${ }^{1}$ \\ Dipartimento di Agraria, Università di Napoli Federico II, Portici (Napoli) Italy. \\ "Corresponding author: antonio.violante@unina.it
}

\begin{abstract}
Rhizosphere is a microsite where interactions among roots, microorganisms, soil constituents (minerals and organic matter), and soil solution take place. Biomolecules produced by plants and microorganisms and soil organic substances are involved in many biogeochemical processes at soil-root interface such as: a) weathering of clay minerals and release of $\mathrm{Al}$ and $\mathrm{Fe}, \mathrm{b}$ ) formation of nanoprecipitates and organo-mineral complexes, c) sorption/desorption of cations and anions on/from soil colloids and d) bioavailability of nutrients and pollutants. Many exudates form strong complexes with $\mathrm{Fe}$ and $\mathrm{Al}$ ions, retard or inhibit their hydrolytic reactions and promote the formation of noncrystalline or short-range ordered $\mathrm{Al}$ and Fe nanoprecipitates. The so-called iron plaques, present on many wetland plant roots, are Fe(III)-oxyhydroxides (mainly ferrihydrite). These precipitates may interact with biopolymers (proteins, polysaccharides, DNA, RNA and so on), phyllosilicates, soil organic substances as well as microorganisms forming organo-mineral complexes. Root exudates play a vital role on the sorption/desorption of nutrients and pollutants at soil-root interface. The processes, which affect the sorption of cations and anions on sorbents present in the rhizosphere are particularly complex, being sorption of cations quite different from that of anions. Root exudates usually inhibit the sorption of anions, but may promote or inhibit the sorption of cations. They may desorb, at least partially, nutrients and pollutants previously sorbed on soil components, promoting their bioavailability for plants and microorganisms. Finally, some plants release chelating organic ligands able to complex metals (e.g. Al) which become less toxic. Many factors control these processes, for example; $\mathrm{pH}$, nature and concentration of the biomolecules present in the rhizosphere, nature of sorbent and sorbate, reaction time.
\end{abstract}

Keywords: Soil-root interface, nanoprecipitates, organomineral complexes, sorption/desorption, nutrients, pollutants

\section{Introduction}

Rhizosphere is the narrow zone of soil influenced by the roots and exudates. The extent of the rhizosphere, which is usually considered to extend from the root surface out into the soil for a few millimeters, may vary with plant species, age of the plant, soil properties, the level of physical, chemical, and biological stress and so on (Hinsinger, 1998; Pinton et al., 2001; Hinsinger et al., 2013). The biological and chemical processes which occur at soil-root interface are dramatically different from those 
occurring in the bulk soil due to the interaction among plant roots, microorganisms and soil components (Hinsinger et al., 2013). More intense microbial activity and larger microbial population occur in this zone than in bulk soil, due to the release by roots of large amounts of organic compounds. Microbial population in the rhizosphere can be 10-100 times larger than the population in bulk soil due to the much higher amount of organic substances present at soilplant interface (Huang and Germida, 2002; Hinsinger et al., 2013). A multitude of compounds are released into the rhizosphere by plants and microorganisms. Rhizosphere $\mathrm{C}$ flow has been estimated to account for a major fraction, up to $30-40 \%$ of plant primary production. Root exudates comprise both highand low-molecular-weight substances released by the roots. The most important high-molecularweight compounds are mucilage, polysaccharides, and ectoenzymes, whereas the main constituents of the low-molecular-weight root exudates are carbohydrates, organic acids, aminoacids, peptides and, phenolics. The relative abundance of organic acids is aliphatic acids $>$ aromatic acids $>$ amino acids. The hydroxyl-, di-, and tricarboxylic acids (e.g., oxalic, malic, succinic, citric, tartaric, and malonic acids) are the most abundant aliphatic acids present in the rhizosphere. Diverse bacteria and fungi produce large amounts of siderophores and some plants release phytosiderophores. These compounds, which are diamino-carboxylic acids, may be excreted into the rhizosphere and might have an important role in the mobilization and uptake of Fe. In addition to having a high affinity for $\mathrm{Fe}(\mathrm{III})$, they can also bind other metals $(\mathrm{Cd}, \mathrm{Zn}, \mathrm{Cu})$. Root products that are not $\mathrm{C}$ compounds are relatively few (protons, inorganic ions, water, electrons).

Biomolecules produced by plants and microorganisms as well soil organic substances are involved in many processes at soil-root interface such as: a) weathering of clay minerals and release of $\mathrm{Al}$ and $\mathrm{Fe}$ (as well as $\mathrm{Ca}, \mathrm{Zn}, \mathrm{Cu}, \mathrm{Mn}$ ) b) formation of nanoprecipitates and organo-mineral complexes, c) sorption/desorption of cations and anions on/from soil colloids, d) bioavailability of nutrients and pollutants, and e) complexation and detoxification of toxic elements.

\section{Interactions between biomolecules and clay minerals: Formation and nature of nanoprecipitates at soil-root interface}

Rhizosphere soil exhibits differences in physicochemical properties and mineralogy compared with bulk soil. It is a major active microsite where interactions among roots, symbiotic microorganisms, bacteria, soil constituents (minerals, organic substances), and soil solution take place and are involved in solubilization and insolubilization processes and the formation of secondary minerals that affect the structure, texture, and reactivity of soil [Figure 1: (Robert and Berthelin, 1985; Huang and Germida, 2002; Gadd, 2008)]. As summarized by Séguin et al. (2005) "the rhizosphere is considered to be a microenvironment that is more acidic than the bulk soil, which contain a greater amount and diversity of organic matter, mainly through rhizodeposition. The soil under root influence generally has a lower $\mathrm{pH}$, although the effect on $\mathrm{pH}$ depends on the nutritional status of the plant. A plant absorbs both anions and cations, but rarely in an equivalent amount. In order to maintain its electroneutrality and that of the surrounding soil solution, the plant must either exsude $\mathrm{OH}^{-}$or $\mathrm{H}^{+}$to equilibrate the anion-cation balance. Based on the literature relating soil acidity, organic matter content, and microorganisms to the intensity of mineral weathering, it can then be expected that mineral weathering will be increased in the rhizosphere". 


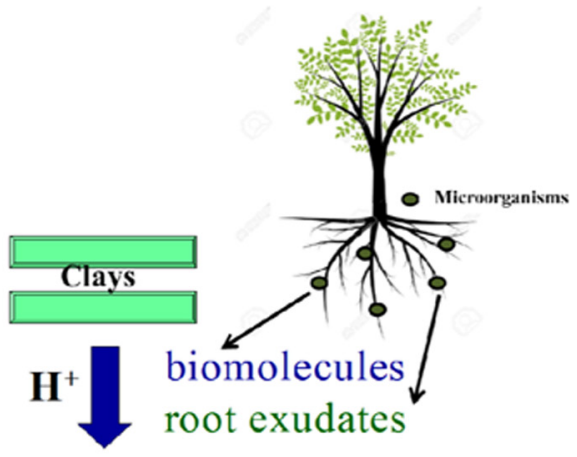

\section{weathering}

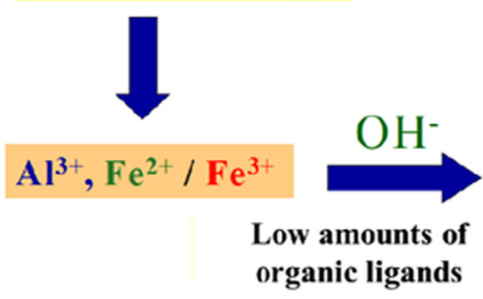

Short range ordered Fe and $A l$ oxides (nanoprecipitates)

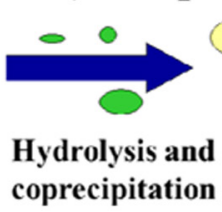

Figure 1. Interaction between root exudates and biomolecules released by plants and microorganisms. Chelating organic ligands promote weathering of clay minerals and the release of Al and Fe. Organic ligands coprecipitate with $\mathrm{Al}$ and Fe, promoting the formation of short-range ordered Al- and Fe-oxides with particles extremely small in size ( $<100 \mathrm{~nm}$; nanoprecipitates).

Chelating root exudates and organic compounds released by microorganisms as well as organic acids are involved in the weathering of minerals and in the subsequent release and transformations of $\mathrm{Fe}$ and $\mathrm{Al}$ at root-soil interface. Their solubilisation capabilities depend on their chemical composition, nature of clay minerals and the mineral element considered (Hinsinger et al., 2013). In particular, the ability of (phyto)siderophores to form stable complexes with $\mathrm{Fe}$ (complex stability constant range from $10^{23}$ to $10^{52}$ ), $\mathrm{Al}$ and other cations suggests that these chelating ligands may influence metal mobility in the rhizosphere by affecting mineral weathering. Such processes of acid dissolution and complexation of minerals due to metabolites are considered as indirect weathering processes. Some bacteria, including anaerobic species, and fungi can attack mineral surfaces and thereby mobilize constituents of the mineral. One of the modes of attack of minerals includes indirect attack with a metabolically produced ligand that form a highly soluble product with a mineral component (Robert and Berthelin, 1985; Ehrlich,2002; Gadd, 2008).

Aluminum and $\mathrm{Fe}$ are released to soil solution through chemical and biochemical processes, undergoes hydrolysis and may give rise to precipitation products (Figure 1). Clay minerals, $\mathrm{pH}$, organic ligands are the most important factors which influence the release and phase transformation of $\mathrm{Al}$ and $\mathrm{Fe}$ at soilplant interface and the mineralogy, order, particle size, specific surface area and reactivity of the metal precipitation products towards nutrients and pollutants. Organic compounds which form stable complexes with $\mathrm{Fe}$ and $\mathrm{Al}$ ions, compete with $\mathrm{OH}^{-}$ 
ions and strongly perturb the hydrolytic reactions, retarding or inhibiting the crystallization of $\mathrm{Fe}$ - and Al-(oxy)hydroxides through occupation of Fe-and Al-(oxy)hydroxides coordination sites (Violante and Huang, 1985; Huang and Violante, 1986; Violante et al., 1993, 2002; Colombo et al., 2005). As a consequence, the formation of noncrystalline or short-range ordered $\mathrm{Al}$ and $\mathrm{Fe}$ precipitates (e.g. ferrihydrite) is promoted at soil-root interface (Figure 1). This behavior is similar to that ascertained in the weathering interface between lichens and rocks (Violante et al., 2011).

The increased weathering of minerals in the rhizosphere induces changes in the abundance and the forms of metals at soil-root interface, as compared to the bulk soil. Greater contents of acid ammonium oxalate (AAO) extractable $\mathrm{Al}$ and $\mathrm{Fe}$ have been found in the rhizosphere than in the bulk soil. AAO solutions are used to extract the inorganic noncrystalline $\mathrm{Al}$ and Fe oxides together with organically complexed metals most of which occur as weathering products in soils. The greater abundance of noncrystalline oxides is then the result of an increase in weathering rates (Séguin et al., 2005).

Many laboratory studies have been carried out on the influence of strongly chelating organic ligands on the nature, size of the particles and crystallinity of $\mathrm{Al}$ and Fe precipitates. These researches have demonstrated that organic chelating anions (e.g. citric, oxalic, malic, tartaric, acid) have a tremendous influence on $\mathrm{Al}$ and $\mathrm{Fe}$ nucleation reactions, their transformations and surface properties of the final precipitation products. These ligands cause structural distortion of these precipitates and, thus, increase their specific surface and reactive sites (Violante et al., 1993, 2002, 2011, 2013). It has been demonstrated that in the absence of ligands well crystallized $\mathrm{Fe}$ or $\mathrm{Al}$ oxides (gibbsite, goethite, hematite, lepidocrocite) forms in few days or weeks at $\mathrm{pH}>4.0$ (Figure 2A), whereas at certain concentrations of strongly chelating ligands ( $\mathrm{L} / \mathrm{Al}$ or Fe molar ratio ranging from 0.01 to 0.1 ) short range ordered precipitates (ferrihydrites, noncrystalline Fe and $\mathrm{Al}$ oxides, poorly crystalline boehmite $[\mathrm{AlOOH}]$ ) form and remain unchanged for years (Figures 2B-D). $\mathrm{X}$-ray diffraction analysis and electron microscope studies showed that some precipitates were noncrystalline even after a long aging period (more than 10 years at $20-50^{\circ} \mathrm{C}$ ) and usually appeared to be agglomerates of spherical particles (Figures 2B and $2 \mathrm{C}$ ), whose size was $<50 \mathrm{~nm}$ (Violante et al., 1993, 2003; Colombo et al., 2005). Other studies demonstrated that the nature and concentration of organic ligands also affected the morphology of shortrange ordered precipitates (Violante et al., 2002). Poorly crystalline boehmite (short-range ordered Aloxyhydroxides, $\mathrm{AlOOH}$ ) formed under certain ionic conditions and showed fibrous morphology, but there were differences in the degree of fiber development depending on the ligand/Al molar ratio, $\mathrm{pH}$, time of aging and temperature (Colombo et al., 2005). Many researchers (Eusterhues et al., 2011; Yuan and Theng, 2011; Liu et al., 2013) have demonstrated that poorly crystalline and noncrystalline Al- and Fe-oxides are very important in stabilizing organic substances.

As reported before biomolecules interact with $\mathrm{Fe}$ released from minerals promoting the formation of poorly crystalline ferrihydrite (Figures $2 \mathrm{C}$ and $2 \mathrm{D}$ ). The degree of ordering of ferrihydrite is variable and a range of X-ray diffraction patterns may be obtained. The two extremes of ordering are referred as 2-line $(0.252$ and $0.148 \mathrm{~nm})$ and 6-line ferrihydrite (additional lines at $0.225,0.197,0.172$, and $0.151 \mathrm{~nm}$ ), because the XRD patterns range from two to six reflections as structural order increases. It is well known that $\mathrm{Fe}$ precipitates, commonly called iron plaques, form on the roots of many wetland plants (e.g. on the surfaces of rice roots; Figures 1 and 2E). Numerous studies suggest that the predominant minerals present in $\mathrm{Fe}$ 
root plaques are $\mathrm{Fe}(\mathrm{III})$-oxyhydroxides, including ferrihydrite (mainly), goethite and lepidocrocite, but also $\mathrm{Mn}$ oxides may form. Iron plaques often contain high concentrations of metals $(\mathrm{Cr}, \mathrm{Pb}, \mathrm{Cu}, \mathrm{Zn} ; \mathrm{Xu}$ and $\mathrm{Yu}, 2013)$. A possible role of iron plaque is to facilitate the uptake and translocation of nutrients and microelements (e.g., Cd), or may act as a barrier reducing the uptake of potentially phytotoxic metals and metalloids (As) by plants. $\mathrm{Xu}$ and $\mathrm{Yu}$ (2013) found that the iron plaque coatings the rice seedling roots appeared to be to XRD 2-line ferrihydrite, but noncrystalline Fe precipitates were probably present being the peaks barely visible (Figure 2F).
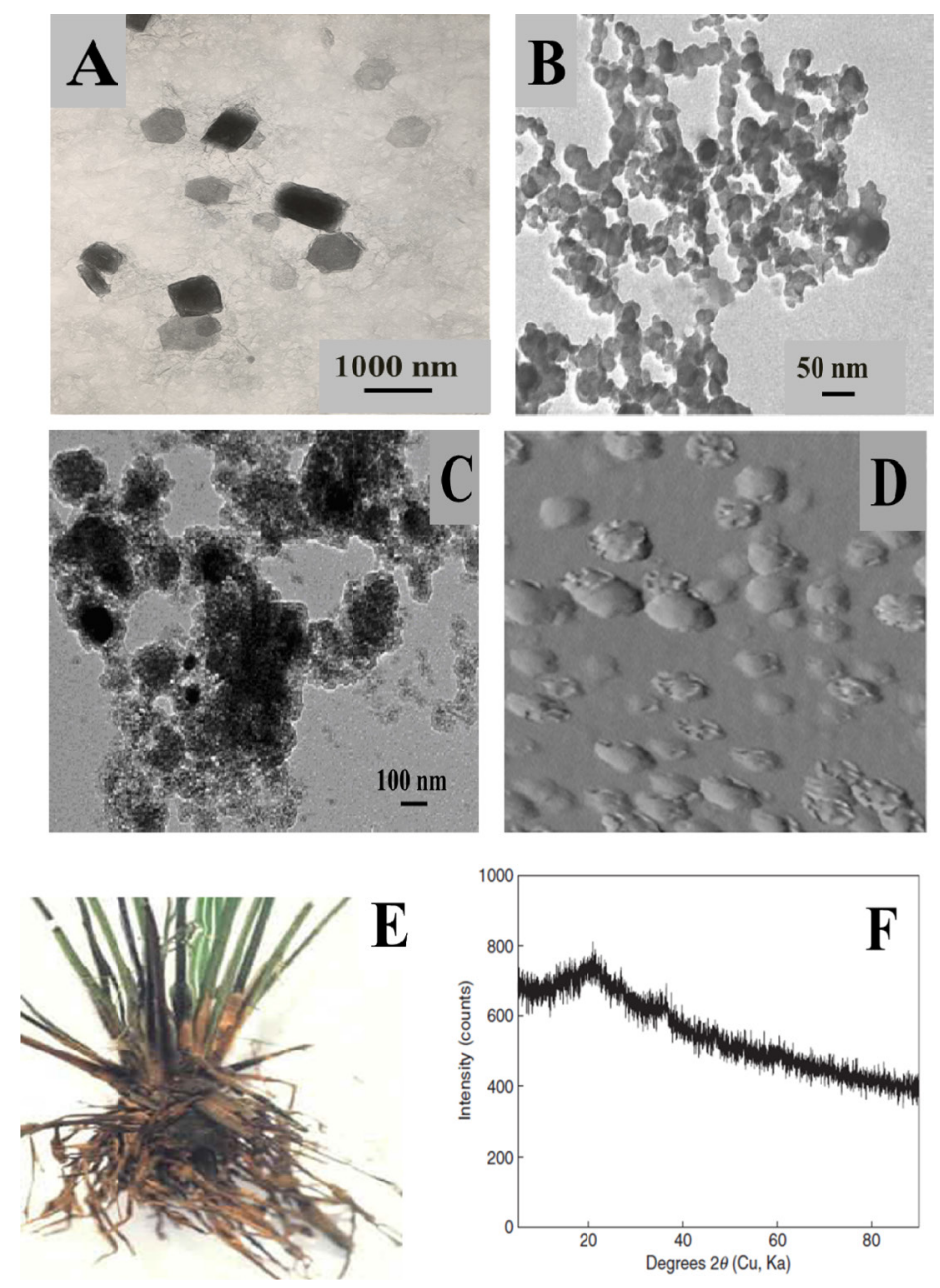

Figure 2. Transmission electron micrographs of (A) gibbsite formed at $\mathrm{pH} 6$ in the absence of organic ligands, (B) noncrystalline Al oxides formed at $\mathrm{pH} 5.0$ at tannate/Al molar ratio of 0.1 aged 9 years at $50^{\circ} \mathrm{C},(\mathrm{C})$ ferrihydrite formed at $\mathrm{pH} 7.0$ and citrate/ Fe molar ratio of 0.1 aged 1 year, (D) an atomic force micrograph of the same sample (C); (E) iron plaques on plant roots, (F) 2-line ferrihydrite in root plaques of rice seedlings detected by XRD. 


\section{Interaction between abiotic and biotic soil components: Formation of organo-mineral complexes}

Root exudates [low molecular mass organic ligands (LMMOLs) as well as biopolymers (e.g. proteins (enzymes), nucleotides, polysaccharides, lipids] interact with clay minerals, $\mathrm{OH}-\mathrm{Al}$ and $\mathrm{OH}-\mathrm{Fe}$ species and/or microorganisms forming organo-mineral complexes (Theng, 1979; Violante and Huang,1989; Violante and Gianfreda, 2000; Violante et al., 2002; 2003; 2011; Yuan and Theng, 2011) (Figure 3).

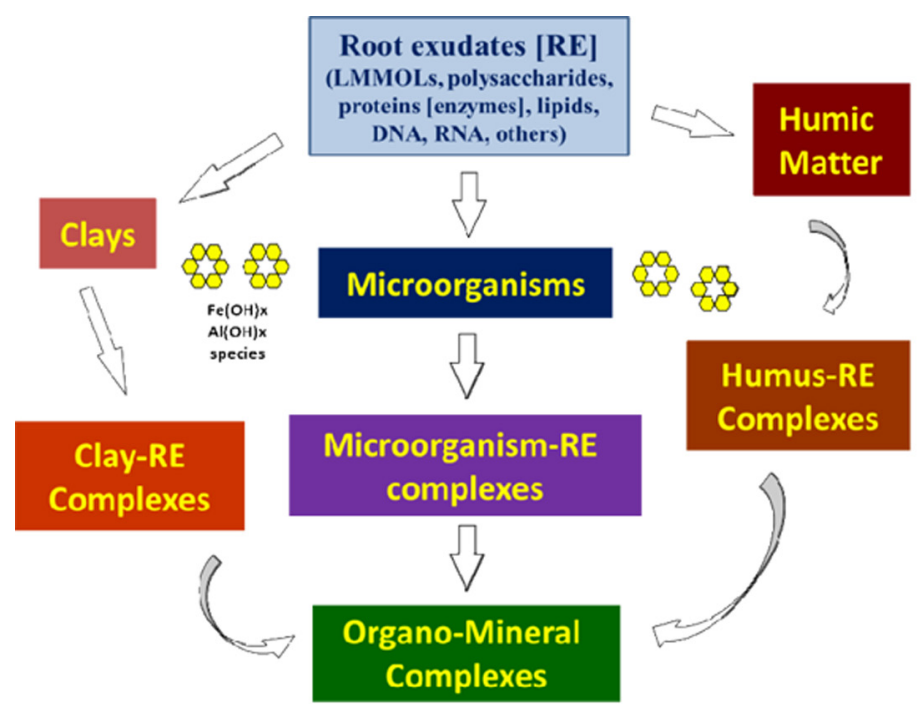

Figure 3. Interactions of root exudates with soil components (clay minerals, $\mathrm{Fe}(\mathrm{Al})(\mathrm{OH}) \mathrm{x}$ species, humic matter, microorganisms) forming organo-mineral complexes of different complexity.

Microorganisms-mineral complexes, which form by electrostatic or hydrophobic interaction between microorganisms and minerals are other common complexes at soil-plant interface. Microorganisms participate in the formation of organo-mineral complexes in which these complexes provide substrates and protection. They contribute to the formation of organo-mineral complexes excreting polysaccharides and proteins (Kogel-Knaber et al., 2008; Yuan and Theng, 2011).

Because of the complexity of natural organo-mineral complexes, many studies have been carried out on the nature, reactivity and activity (if active biopolymers [e.g. enzymes] were present) of synthetic complexes obtained by the interaction among two or more soil components (abiotic and biotic). Short-range order minerals, $\mathrm{OH}-\mathrm{Al}$ and $\mathrm{OH}-\mathrm{Fe}$ species are particularly important in stabilizing organic substances in soil environments, because usually organic molecules (LMMOLs, (phyto)siderophores as well as biopolymers) are strongly fixed on these sorbents forming inner-sphere complexes (Violante, 2013). Organic matter associated with (oxalate-extractable) $\mathrm{Fe}$ and $\mathrm{Al}$ is potentially stable for thousands of years (Yuan and Theng, 2011). Organic compounds are sorbed on the surfaces of phyllosilicates or 
even intercalated into the interlayers of expandable clays (montmorillonite, vermiculite) only at low $\mathrm{pH}$ (say $\mathrm{pH}<5$ ) where they do not present a negative charge. However, polyvalent cations but mainly Al$\mathrm{OH}$ and $\mathrm{Fe}-\mathrm{OH}$ species, facilitate the sorption of organic substances onto phyllosilicates. It has been demonstrated that monomers, polymers and solid species of $\mathrm{Al}$ and $\mathrm{Fe}$ can react with organic compounds forming complexes which may present a positive or neutral charge and, then, may be easily sorbed on the external negative surfaces of phyllosilicates and may be intercalated into the interlayers of montmorillonite even in neutral or alkaline environments. Many studies have also been carried out on the interaction between biopolymers (mainly proteins [enzymes] with phyllosilicates and/or humic acids (or other organic substances) (Theng, 1979; Burns, 1986; Violante and Gianfreda, 2000; Gianfreda et al., 2011). Proteins may be easily adsorbed and intercalated in the interlayers of montmorillonite, but the amounts of proteic molecules sorbed and intercalated are affected by $\mathrm{pH}$, size and isoelectric point of proteins. Much evidence seems to demonstrate that large biopolymers or organomineral complexes with a net positive or even neutral charge may be intercalated into the lamellar spaces of expansible phyllosilicates. However, when biopolymers or organomineral complexes are particularly large they may be sorbed only on the external surfaces of clay minerals. Only small amounts of proteins may be adsorbed on the surfaces of phyllosilicates when the $\mathrm{pH}$ of the system is higher than the isoelectric point of the proteic molecules.

Sorption and residual activity of active proteins (enzymes) is of paramount importance for understanding the behavior and fate of extracellular proteinic molecules in the rhizosphere. As reviewed by many authors (Burns, 1986; Gianfreda and Bollag, 1996; Violante and Gianfreda, 2000; Gianfreda et al.,
2011) synthetic complexes, obtained by immobilizing enzymes onto clay minerals, humic acids or humicclay composites, were used to study the properties of soil-bound enzymes. Numerous researches have demonstrated that enzymes immobilized on soil components or their composites reduced drastically their activity (up to $80 \%$ ).

The nature, physico-chemical properties and reactivity (as will be discussed later) of organomineral complexes are affected not only by the nature and amount of each soil component, both abiotic and biotic, involved in the formation of the complexes but also by the sequence of addition of the components involved in their formation. Studies have been carried out on the influence of the sequence of addition of montmorillonite, hydroxyl-Al species and humic acids, tannic acid or proteins. The different sequence addition of $\mathrm{OH}-\mathrm{Al}(\mathrm{Fe})$ species, montmorillonite and large organic ligands promote the formation of complexes with different d-spacing and surface properties, which are attributed to differences in the nature of OH-Al-organomineral complexes and different interlayering of $\mathrm{OH}-\mathrm{Al}$ species and biomolecules. Some authors (Buondonno et al., 1989; Buondonno and Violante, 1991; Violante et al., 1999) studied the influence of the sequence addition of montmorillonite, hydroxy-Al species and humic or tannic acids on the nature of organo-clay complexes formed at $\mathrm{pH}$ 4.5-7.0. Negligible amounts of humic or tannic acids were held on the clay surfaces in the absence of Al, whereas in the presence of Al, hydroxylAl-humate or tannate complexes were easily sorbed on clay surfaces. Their distribution on the external surface and in the interlayer space of montmorillonite was a consequence of how the components reacted with each other. The final complexes also showed distinct differences in cation exchange capacity (CEC), carbon content, extractable $\mathrm{Al}$, titratable acidity, and mode of aggregation after drying. Later, 
De Cristofaro and Violante (2001) studied the effect of the sequence of addition of $\mathrm{OH}-\mathrm{Al}$ species, protein molecules (albumin) and montmorillonite as well as $\mathrm{pH}$ on the nature and surface properties of the final protein-OH-Al-montmorillonite complexes (Figure 4). They demonstrated that $\mathrm{OH}-\mathrm{Al}$ species initially added to the clay were previously interlayered and consequently prevented the intercalation of the proteinic molecules, which were sorbed on the external surfaces (Case I: Al(OH)x + Mt before Alb system). In contrast, when $\mathrm{OH}-\mathrm{Al}$ species and proteins were added to the clay as a mixture, large $\mathrm{OH}-\mathrm{Al}-$ protein polymers formed, which were only partially intercalated into the interlamellar spaces of the clay (Case II: $\mathrm{Al}(\mathrm{OH}) x+$ Alb before $M t$ system). Finally, when albumin was added to montmorillonite before $\mathrm{OH}-\mathrm{Al}$ species (Case III: Alb + Mt before $\mathrm{Al}(\mathrm{OH}) x$ system) the proteinic molecules were able to penetrate easily into the interlayers of montmorillonite. X-ray diffraction patterns (Figure 4D) showed that intercalation of albumin occurred more easily in the $\mathrm{Alb}+\mathrm{Mt}$ before $\mathrm{Al}(\mathrm{OH}) \mathrm{x}$ system (d-spacing of $2.441 \mathrm{~nm}$ ) than $\mathrm{A}(\mathrm{OH}) x \mathrm{l}+\mathrm{Mt}$ before $\mathrm{Alb}$ and $\mathrm{Al}(\mathrm{OH})$ $x+$ Alb before Mt systems (d-spacings of 1.864 and $1.497 \mathrm{~nm}$, respectively) in the order listed. When an enzyme (urease) was used the residual activity of complexes obtained by differently mixing the enzyme with $\mathrm{OH}-\mathrm{Al}$ or $\mathrm{OH}-\mathrm{Fe}$ species and clay minerals was substantially different (Violante, unpublished data). As reviewed by Burns, 1986; Violante and Gianfreda (2000) and Gianfreda et al. (2013) the residual activity of selected enzymes onto phyllosilicates, $\mathrm{Al}[\mathrm{Fe}]$-oxides, tannate or humic acids and their binary and ternary complexes has been extensively studied.
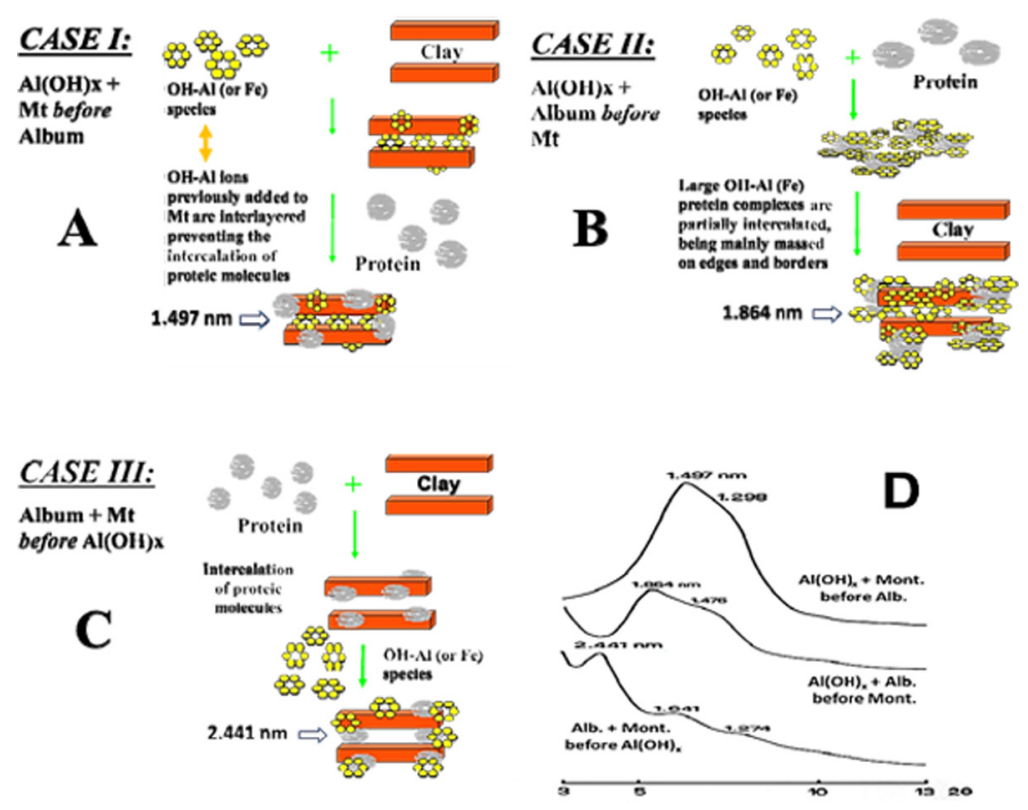

Figure 4. Schematic representation of the sorption of albumin onto montmorillonite (Mt) in the $\mathrm{Al}(\mathrm{OH}) \mathrm{x}-\mathrm{Mt}$ complexes, obtained by differently mixing $\mathrm{Al}(\mathrm{OH}) \mathrm{x}$ species, albumin and montmorillonite in order to have three diverse systems: $\mathrm{Al}(\mathrm{OH}) \mathrm{x}$ + Mt before protein (Case I, A), $\mathrm{Al}(\mathrm{OH}) \mathrm{x}+$ protein before Mt (Case II, B), and protein + Mt before $\mathrm{Al}(\mathrm{OH}) \mathrm{x}(\mathrm{Case}$ III, C). (D) $\mathrm{X}$-ray diffraction patterns of the complexes described above (A-C) (Modified from De Cristofaro and Violante, 2001). 


\section{Sorption and desorption processes at soil-plant interface}

Mobility of elements at soil-plant interface is affected by sorption-desorption reactions, which are the predominant factors that control their bioavailability. The soil components responsible for the sorption of nutrients and pollutants include phyllosilicates, soil organic matter, carbonates, variable charge minerals (crystalline and short-range ordered Fe-, Al-, Mnoxides, phyllosilicates coated by $\mathrm{OH}-\mathrm{Al}$ and $\mathrm{OH}-$ $\mathrm{Fe}$ species), microorganisms and organomineral complexes. Soil components differ greatly in their sorption capacities, their cation and anion exchange capacities, and the binding energies of their sorption sites.

Two surface complexes exist and are described by the configuration geometry of the sorbate at the sorbent surface. These include inner- and outer-sphere surface complexes (Borda and Sparks, 2008;Sparks, 2002). Outer-sphere complexes involve electrostatic coulombic interactions, and are thus weak compared with inner-sphere and are reversible. Inner-and outersphere complexations can occur simultaneously. Specific sorption is characterized for higher selectivity and stronger binding (weaker reversibility), while nonspecific sorption is known for lower selectivity and greater reversibility. The strength of the sorption of cations and anions is an important factor governing their mobility in soils.

Sorption of elements onto soil components is influenced by many factors as $\mathrm{pH}$, nature of the sorbents, redox reactions, presence of foreign ions, as reported by many authors (Sparks, 2002; Violante et al., 2002; Violante, 2013). Briefly, cations show typical ion exchange behavior on clay minerals. Surface bonding is prevalently electrostatic, but polyvalent cations (e.g. $\mathrm{Zn}, \mathrm{Cu}, \mathrm{Cd}, \mathrm{Co}, \mathrm{Ca}$ ) may be strongly adsorbed on the edge sites of phyllosilicates due to the presence of $-\mathrm{SiOH}$ or $-\mathrm{AlOH}$ groups capable of chemisorbing these ions. Organic matter and variable charge minerals (metal oxides, allophanes, imogolite) are much more effective scavenger of polyvalent cations, because complexation processes are the dominant binding mechanisms (Huang and Germida, 2002; Violante et al., 2002; 2008; Violante, 2013). Polyvalent cations are usually sorbed on these sorbents forming inner-sphere complexes.

Evidence on the sorption of metal cations on microorganisms has been reported. Free-living bacteria and their extracellular macromolecular products (e.g. fibrils) can accumulate metal ions and may have mineral coatings with bound metals on their surfaces (Chenu and Stotzky, 2002). The cell surfaces of all bacteria are largely negatively charged, containing different types of negatively charged functional groups, such as carboxyl, hydroxyl, and phosphoryl that can sorb metal cations. Biosorption comprises a variety of processes, including ion exchange, chelation, sorption, and diffusion through cell walls and membranes all of which are dependent on the species used, the biomass origin, and solution chemistry (Chenu and Stotzky, 2002).

Anions sorb primarily to variable charge minerals (metal oxides and noncrystalline aluminum silicates, allophanes), carbonate, and at the edges of phyllosilicates. Usually, they are not sorbed on soil organic matter, but certain elements (e.g. borate, arsenate, arsenite) are found to be bound to humic substances (Kampf et al., 2000; Sparks, 2002; Violante et al., 2008, 2011).

Sorption of anions onto variable charge minerals and soils varies with $\mathrm{pH}$. With increasing $\mathrm{pH}$ values, within a certain range, sorption decreases (due to a decrease in the positive charge of minerals) or else increases to a maximum close to the $\mathrm{pKa}$ for anions of monoprotic conjugate acids and then decreases. Ligands that are specifically sorbed, forming inner-sphere complexes, 
replace $-\mathrm{OH}^{-}$or $-\mathrm{OH}_{2}$ groups from the surfaces of variable charge minerals. Ligands, which form innersphere complexes, such as phosphate, arsenate, arsenite (on Fe-oxides), molybdate, selenite, and polydentate chelating low-molecular mass organic ligands (LMMOLs, e.g. oxalate, citrate, tartrate, malate) or soil organic substances, may form different surface complexes on inorganic soil components: monodentate, bidentate-binuclear and bidentatemononuclear complexes in different proportions depending on the $\mathrm{pH}$ and surface coverage (Sparks, 2002; Figure 5).

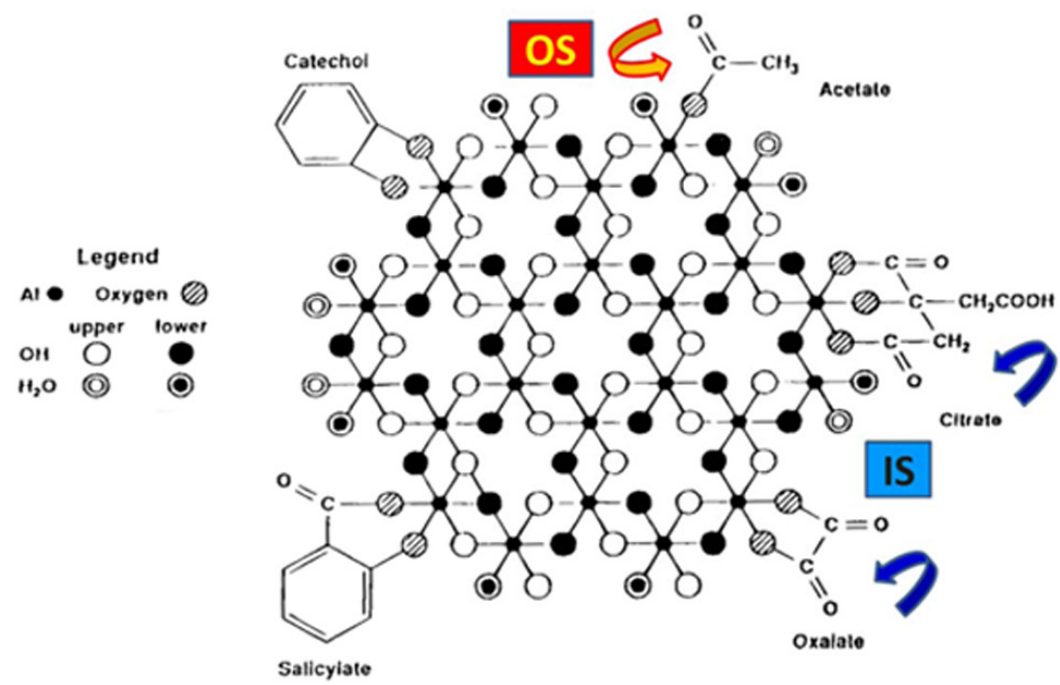

Figure 5. Examples of interactions between selected root exudates and an Al-oxide, forming monodentate, bidentate or tridentate complexes (inner-sphere [IS] or outer-sphere [OS]) (Modified from Vance et al., 1996).

Sulfate and selenate seem to be able to form only outer-sphere complexes (Sparks, 2002; Pigna et al., 2007). However, there is some spectroscopic evidence that sulfate can also be sorbed as an inner-sphere complex. Recent studies have demonstrated that sulfate may be sorbed onto the surfaces of variable charge minerals, forming both inner-sphere and outersphere complexes, with the former occurring mainly at $\mathrm{pH}<<6.0$ and increasing sulfate concentrations. The halide anions, with the exception of fluoride, and organic monocarboxylic (acetate) anions bond by outer-sphere electrostatic attraction and are sorbed only if variable charge minerals surfaces are positively charged ( $\mathrm{pH}<\mathrm{PZC}$ of the sorbents) (Figure 5).

\section{Role of biomolecules on the mobility of elements at soil-root interface}

Root exudates and organic substances released by microorganisms (mainly LMMOLs) play a vital role on the sorption/desorption of elements on/from soil components and organo-mineral complexes and then 
on their availability for plants and soil organisms. In Figure 6 is depicted a model of exudates flux in the rhizosphere and its influence on the mobility of nutrients and pollutants. Sorption/desorption processes of cations are different from those of anions.



Figure 6. A possible model of biomolecules (root exudates and [phyto]siderophores) flux in the rhizosphere, which affect the sorption/desorption of nutrients and pollutants.

\subsection{Effects of biomolecules on the mobility of cations}

Sorption of elements in cationic form onto soil components may be either enhanced or inhibited by the presence of organic acids (as oxalic, citric, malic, tartaric, malonic acid) and aminoacids through different processes, including alteration of surface charge, site competition, formation of different complexes in solution, ternary complex formed on the surfaces of soil components (Sparks, 2002; Violante, 2013). Ternary surfaces complexes may be classified as type $\mathrm{A}$, in which the metal ion is bonded to both the sorbent and the organic ligand, or type $\mathrm{B}$, in which the ligand is bonded to the sorbent between the surface and the metal ion (Figure 7). The structure of sorbed species determines their stability and the extent of metal ion partitioning from solution to solid phase (Alcacio et al., 2001).

Organic ligands usually inhibit the sorption of cations on negatively charged sorbents, as phyllosilicates, organic matter and microorganisms, by forming stable soluble negatively charged complexes with polyvalent cations. Some authors (Wuet al., 2003; Violante, 2013) demonstrated that various LMMOLs inhibited at different degrees the sorption of cations onto phyllosilicates (see Violante, 2013, his Figure 3.2). The influence of chelating organic ligands on the sorption of polyvalent cations onto soil organic matter and organo-mineral complexes has received attention. Usually, they compete with organic substances and 
reduce cation sorption. Wu et al. (2003) found that the amount of $\mathrm{Pb}$ sorbed onto soil organic matter decreased with increasing concentration of EDTA, clearly because EDTA very strongly complexes with $\mathrm{Pb}$ ions and prevents their fixation on soil organic matter.

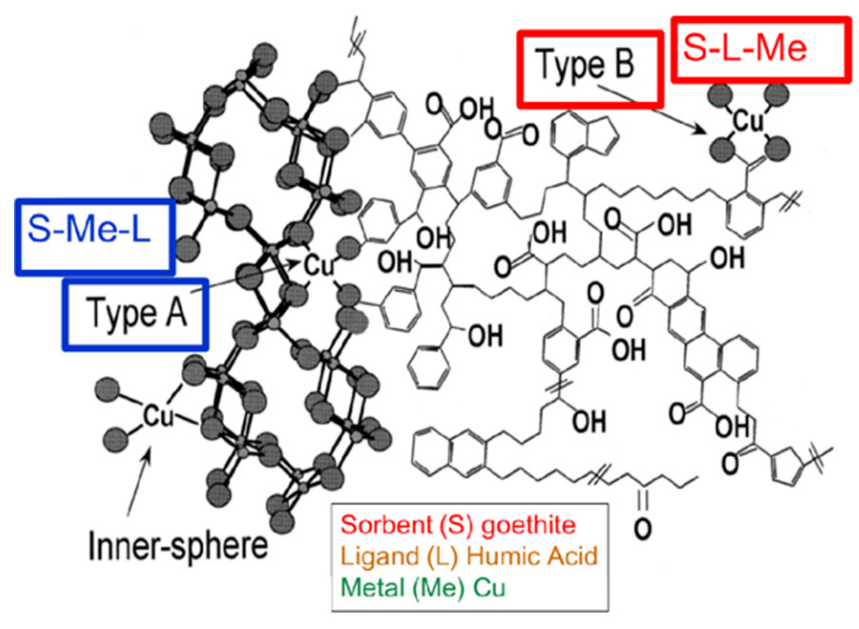

Figure 7. Illustration of some possible bonding configurations of $\mathrm{Cu}(\mathrm{Me})$ on goethite (S)-organic matter (L) complexes: innersphere complexation of $\mathrm{Cu}$ at goethite sites, and type-A- (S-Me-L) and B-(S-L-Me) ternary complexes (Modified from Alcacio et al., 2001).

The sorption of polyvalent cations in the presence of biomolecules onto the surfaces of variable charge minerals (iron and aluminum oxides, allophanes, imogolite) may be affected by several processes, which may occur simultaneously: (i) increased retention of metal cations for the decrease of the positive charge of the mineral when a ligand is sorbed, (ii) increased retention due to the formation of negatively charged complexes between a metal and a ligand, which have a higher affinity for the sorbent, (iii) decreased retention due to the block of sorption sites by foreign ligands on the minerals, (iv) decreased retention due to the strong complexation of metal in solution in nonsorbing form, with lower free metal activity leading to desorption of surface-bound metal, (v) dissolution of the mineral in the presence of relatively high concentration of chelating organic ligands, leading to lesser metal retention (Sparks, 2002; Violante et al., 2008). In each of the cases described before, the effect of a ligand on the sorption of metal cations depends not only on the strengths of the interactions between metal ion, ligand, and sorbent but also on their concentrations. Certainly, the initial ligand/metal molar ratio, the nature of the ligand and the metal, the surface properties of the sorbent seem to be critical in determining whether the sorption of a cation is enhanced or inhibited.

Further, because anionic ligands are usually sorbed more strongly at low $\mathrm{pH}$, whereas metal cations are fixed more easily at high $\mathrm{pH}$, the same ligand may enhance the sorption of a given metal under some conditions but may suppress it under others. The formation of sorbentmetal-ligand (type A) or sorbent-ligand-metal (type B) ternary complexes (Figure 7) has been suggested 
as the main mechanisms also for the promotive effects of organic ligands on the sorption of metal cation onto variable charge minerals.

\subsection{Effect of (phyto)siderophores on the sorption of cations}

(Phyto)siderophores are low molecular weight organic ligands secreted by aerobic microorganisms and some plants, to acquire Fe. They can also form stable complexes with other metals, such as $\mathrm{Zn}, \mathrm{Cu}, \mathrm{Cd}, \mathrm{Pb}, \mathrm{Al}$, $\mathrm{Ga}$, Pd. These biomolecules have an important impact on cations mobility in the rhizosphere. They have a behavior different from that of strongly chelating organic acids (as discussed before. Neubauer et al. $(2000,2002)$ studied the influence of desferrioxamine $\mathrm{B}(\mathrm{DFO}-\mathrm{B})$ on the sorption of $\mathrm{Cu}, \mathrm{Zn}$ and $\mathrm{Cd}$ onto montmorillonite (Figure 8) and kaolinite. In acidic systems and in the absence of DFO-B only small amounts of these elements were sorbed on phyllosilicates. The presence of DFO-B promoted the sorption of $\mathrm{Cu}, \mathrm{Zn}$ (Figure $8 \mathrm{~A}$ ) and $\mathrm{Cd}$ on montmorillonite, palygorskite and sepiolite (Neubauer et al., 2000; 2002; Shirvani et al., 2006). Studies on the sorption of rare earth elements and actinides on Pseudomonas fluorescens cells also demonstrated that in the presence of DFO-B the sorption of these elements substantially increases. Electrostatic interactions between the negative surfaces of phyllosilicates or bacterial cells and DFO-B-Me complexes are the reasons for enhanced metal cation sorption onto these sorbents.
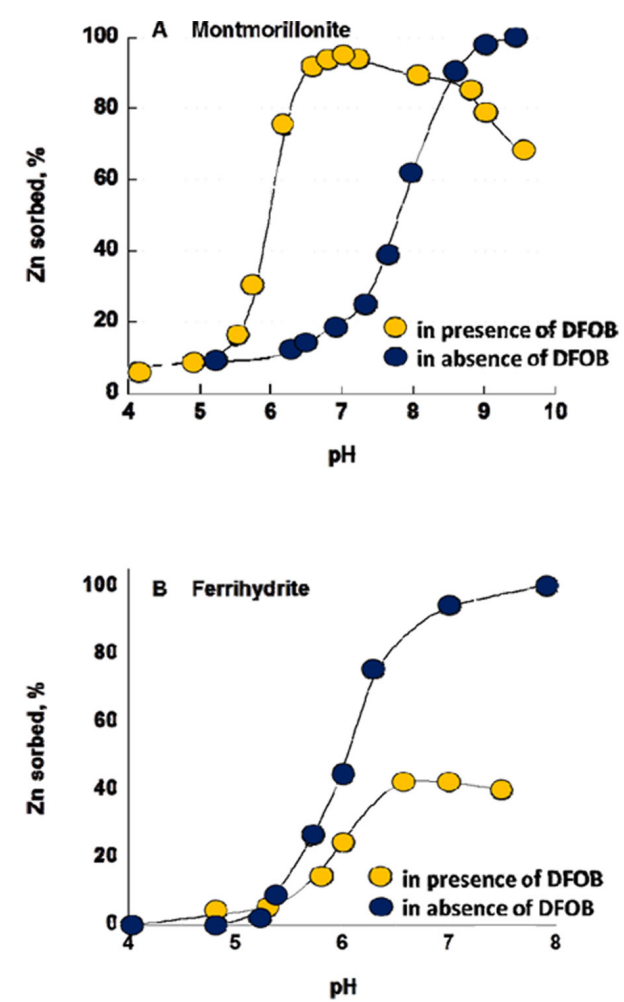

Figure 8. Sorption of $\mathrm{Zn}$ as a function of $\mathrm{pH}$ in the absence and presence of the hydroxamatesiderophore DFOB on (A) montmorillonite (Zn concentration $87 \mu \mathrm{mol} / \mathrm{L})$ and (B) ferrihydrite (Zn concentration $10 \mu \mathrm{mol} / \mathrm{L})$ (Modified from Neubauer $e t$ al., 2002). 
The sorption of $\mathrm{Cu}, \mathrm{Zn}, \mathrm{Pb}, \mathrm{Eu}(\mathrm{III})$ on variable charge minerals (ferrihydrite, boehmite, goethite) in the presence of DFO-B was different from that onto montmorillonite or bacterial cells, which present negative sorption sites. Their sorption on these sorbents was strongly prevented, because positively charged DFO-B-Me complexes are not attracted by the positively charged surfaces of ferrihydrite, goethite and boehmite (Neubauer et al., 2002; Hepinstall et al., 2005).

The effect of four different trihydroxamate siderophores (including DFO-B) on $\mathrm{Pb}$ and $\mathrm{Cd}$ sorption to kaolinite at $\mathrm{pH} 4.5$ to 9.0 was also studied by Hepinstall et al. (2005). These authors demonstrated that at $\mathrm{pH}>6.0$ all of the studied ligands decreased $\mathrm{Pb}$ sorption (from 5 to $75 \%$ ), the greater effects were at higher $\mathrm{pH}$. The same siderophores decreased $\mathrm{Cd}$ sorption onto kaolinite at $\mathrm{pH}>8.0$. This behavior must be ascribed to the fact that kaolinite presents much more variable sites than montmorillonite. Anyway, these authors also observed a slight increase in sorption of $\mathrm{Pb}$ from $\mathrm{pH}$ 5.0-6.0 in the presence of DFO-B onto kaolinite probably due to sorption of the doubly positive charged $\mathrm{H}_{3} \mathrm{~Pb}(\mathrm{DFO}-\mathrm{B})^{2+}$ on the permanent negative sites of this mineral. Hepinstall et al. (2005) concluded that siderophores have the ability to either enhance or inhibit metal mobility at soil-root interface and that further researches are necessary in order to understand the factors (molecular structure and concentration of different siderophores, nature of the sorbents, $\mathrm{pH}$, and nature of heavy metals) which affect the mobility of polyvalent cations.

Several plant species are able to release organic acids from their roots in response to toxic elements (e.g. monomers of $\mathrm{Al}$ ) present in the rooting medium while others release these compounds when growing under a deficient supply of iron or phosphate (as discussed below). Some of them are involved in energy production as intermediates in the tricarboxylic acid cycle (e.g. citrate, malate, oxalate, tartrate), while others are directly or indirectly involved in many other metabolic processes. Because these organic acids are strongly chelating agents, they can form strong complexes with $\mathrm{Al}$ and heavy metals thereby reducing their activity in solution and toxicity to roots (Figure 9).



Figure 9. Tolerant plants release large amounts of chelating organic ligands (oxalate, malate, citrate, tartrate) which complex Al species which become less toxic and do not enter into the plant roots. 


\subsection{Effect of root exudates on the sorption of anions}

The effect of root exudates on the sorption of nutrients and toxic elements in anionic form (phosphate, sulfate, selenite/selenate, arsenate/arsenite, molibdate) has received great attention because the supply of these anions to plants should be strongly influenced by the nature and concentration of root exudates.

The competition between anions (e.g. LMMOLs and phosphate or sulfate) is not only competition for the occupancy of sites available on the sorbents but it also involves a change in the electric potential of the surfaces due of the sorbents (Barrow et al., 2005; Violante, 2013).

Among the first studies on the influence of LMMOLs on phosphate sorption are those of Deb and Datta (1967) and Nagarajah et al. (1970) (cited by Violante and Gianfreda, 2000). These authors found that the competitive ability of carboxylic acids in preventing phosphate sorption on kaolinite, gibbsite, goethite and different soils was in the order citrate $>$ oxalate $>$ malonate $>$ tartrate $>$ acetate. Violante et al. (1991), Violante and Gianfreda (1995) and De Cristofaro et al. (2000) demonstrated that the competitive sorption of phosphate and organic ligands (oxalate, tartrate, succinate and malate) on variable charge minerals was influenced by $\mathrm{pH}$, nature of ligand, order of anion addition, and initial ligand/phosphate molar ratio. Maximum reduction in phosphate addition occurred when an organic ligand was introduced before phosphate, whereas minimum reduction occurred when phosphate was introduced before an organic ligand. The efficiency of organic ligands in preventing phosphate sorption was affected by the nature of the surfaces of soil components and soils.

Many studies have demonstrated that LMMOLs inhibit sulfate sorption much more than phosphate (Liu et al., 1999; Jara et al., 2006; Violante et al., 2005). Martinez et al. (1998) studied the effect of 13
LMMOLs (eight aliphatic and five aromatic) on the sorption of sulfate on two variable charge soils. These soils, containing large amounts of citrate-dithionitebicarbonate (CDB)-extractable $\mathrm{Al}$ and $\mathrm{Fe}$, sorbed significant amounts of sulfate at $\mathrm{pH} 4.0$ and 5.0. All the aliphatic acids, but cis-aconitic acid, prevented the sorption of sulfate, at both $\mathrm{pH} 4.0$ and 5.0, with oxalic, tartaric, and citric acid, showing the greatest effect. Conversely, the aromatic acids and cis-aconitic acid usually increased sulfate sorption under certain conditions, probably because once sorbed these acids promoted the protonation of surface hydroxyl groups, thus creating a more positively charged surfaces.

Competition in sorption among phosphate or sulfate with LMMOLs in ternary systems, received some attention. He et al. (1999) found that the sorption capacity of phosphate onto $\mathrm{Al}(\mathrm{OH}) \mathrm{x}$-montmorillonite complexes was much greater than that of oxalate and tartrate. Adding equimolar amounts of oxalate and tartrate resulted in an oxalate sorbed/tartrate sorbed molar ratio of $\sim 1$. Anyway, in the presence of phosphate the oxalate/tartrate molar ratios were $<1$ and decreased with increasing phosphate concentration, indicating that tartrate competed with phosphate more than oxalate for the sites common to all the ligands. Further, tartrate and oxalate added as a mixture were much more effective in inhibiting phosphate sorption than was tartrate or oxalate alone, probably because more sites with high affinity for the organic ligands were occupied by tartrate and oxalate than by tartrate alone.

The mutual interaction of sulfate, oxalate, citrate, and phosphate in binary and ternary systems on synthetic and natural allophanic samples at different $\mathrm{pH}$ values (4.0-7.0) was studied by Jara et al. (2006). The sorption capacity of sulfate, citrate, and oxalate (in the order listed) was much lower than that of phosphate. The sorption of sulfate was strongly inhibited in the presence of equimolar amounts of oxalate, citrate, 
or phosphate even at low surface coverage of all the ligands. The lower the final $\mathrm{pH}$ of the binary systems, the greater the inhibition of sulfate sorption. On the contrary, sulfate very poorly prevented the sorption of the other ligands (usually lower than 10\%). Figure 10 shows that more citrate than sulfate was adsorbed

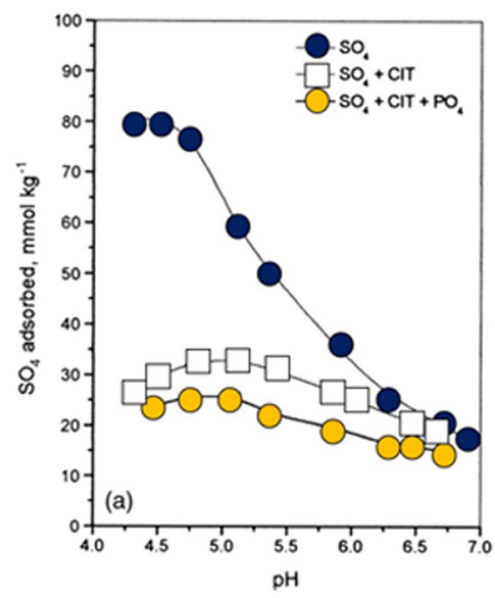

at comparable $\mathrm{pH}$ values. Citrate strongly inhibited sulfate sorption mainly at $\mathrm{pH}<6.0$, whereas sulfate very poorly inhibited citrate sorption. In ternary systems (sulfate+citrate+phosphate) the sorption of sulfate (Figure 10A) decreased much more than that of citrate (Figure 10B).

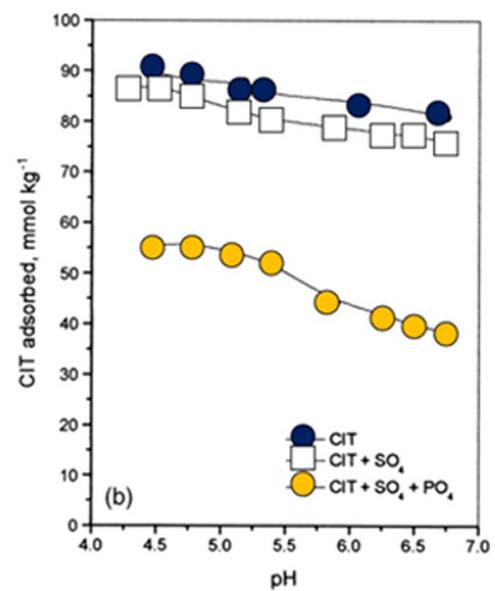

Figure 10. Sorption of $(\mathrm{A})$ sulfate $\left(\mathrm{SO}_{4}\right)$ and $(\mathrm{B})$ citrate $(\mathrm{CIT})$ on a synthetic allophane at different $\mathrm{pH}$ values, when added alone or in a binary $\left(\mathrm{SO}_{4}+\mathrm{CIT}\right)$ or ternary $\left(\mathrm{SO}_{4}+\mathrm{CIT}+\mathrm{PO}_{4}\right)$ systems (Modified from Jara et al., 2006).

It has been demonstrated that root exudates strongly inhibit the sorption of toxic anions (selenite, chromate, arsenate and arsenite) onto different sorbents (Violante, 2013). Zhu et al. (2011; 2013) studied the effect of organic ligands on the sorption of arsenite and arsenate on ferrihydrite and noncrystalline Al precipitation product. The efficiency of the anions studied in preventing arsenite and arsenate sorption was as follows: oxalate $<$ malate $\approx$ tartrate $<$ citrate. The efficiency of most of the competing anions in inhibiting the sorption of the metalloid on ferrihydrite decreased by increasing the $\mathrm{pH}$. In acidic environments, all the ligands prevented the sorption of arsenite more than that of arsenate, but in alkaline systems, arsenite and arsenate seemed to be retained with the same strength. In contrast, on amorphous $\mathrm{Al}$ oxides higher sorption of arsenate versus arsenite was always evidenced in a wide range of $\mathrm{pH}$, both in the absence or presence of organic ligands. Caporale et al. $(2011 ; 2013)$ evaluated the arsenite and arsenate sorption capacity of a Fe-Mg layered double hydroxide at varying $\mathrm{pH}$ values in presence of citrate, oxalate or tartrate (Figure 11). They observed that this sorbent was able to held a much higher amount of arsenate than arsenite and noted that the sorption of the former was much more $\mathrm{pH}$-dependent than the latter. These authors also found that greater percentages of arsenite than arsenate were replaced by selected LMMOLs. 


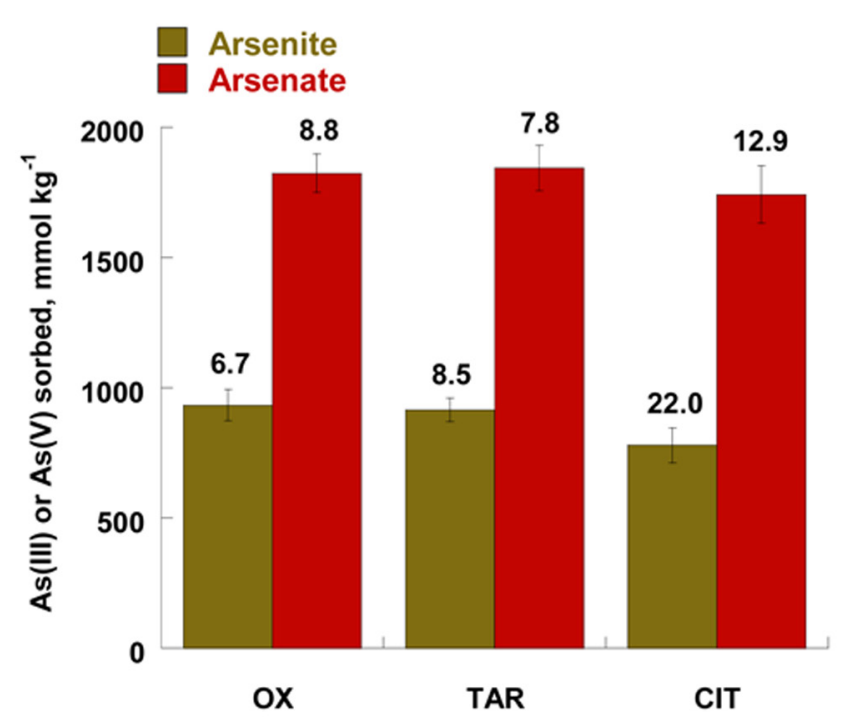

Figure 11. Arsenite and arsenate sorbed on Mg-Fe-LDH, in presence of selected LMMOLs [oxalate (OX), tartrate (TAR) and citrate (CIT)], at $\mathrm{pH} 6.0$ and $20^{\circ} \mathrm{C}$, after $24 \mathrm{~h}$ of reaction time. As(III) or As(V) / LMMOL molar ratio of 1; As(III) and As(V) initially added $=1000$ and $2000 \mathrm{mmol} \mathrm{kg}^{-1}$, respectively. Number above bars indicate efficiency (\%) of LMMOLs in inhibiting $\mathrm{As}(\mathrm{III})$ or $\mathrm{As}(\mathrm{V})$ adsorption by $\mathrm{Mg}-\mathrm{Fe}-\mathrm{LDH}$.

\subsection{Sorption/desorption of nutrient and pollutants on/from organo-mineral complexes}

The reactivity of the colloids formed at soil-root interface results from complex interactions between clay minerals, (oxy)hydroxides, organic matter and/ or microorganisms of soils (Figure 3). The sorption/ desorption equilibria and kinetics of anionic and cationic species on/from natural colloids could substantially differ compared with their interaction with pure soil components.

The role of root exudates present in organomineral complexes on the sorption of anions and cations has received attention. In soil environments, depending on the mechanisms of their interfering reactions, organic substances have a dual role of both hindering or promoting anion retention by the $\mathrm{Al}$ or Fe precipitation products. As discussed before maintenance of shortrange structure of the precipitates (e.g. Al or Fe oxides as iron plaques; Figures 1 and 2) with a large surface area by the presence of critical concentrations of some biomolecules helps to promote a high retention capacity of organo-mineral complexes if compared with $\mathrm{Fe}$ and $\mathrm{Al}$ oxides formed in absence of organic ligands characterized by greater crystallinity and lower surface area, but the presence of organic ligands into the complexes also prevents the sorption of nutrients and pollutants.

Violante and coworkers (Violante and Huang, 1989; Violante and Gianfreda, 2000; Violante, 2013) carried out some works on the sorption of phosphate and sulfate by organomineral complexes formed 
by coprecipitating $\mathrm{Al}$ in the presence of LMMOLs (oxalate, aspartate, citrate, tartrate, tannate). Figure 12 shows the sorption of phosphate on and the partial removal of oxalate from a noncrystalline $\mathrm{Al}(\mathrm{OH})$ $\mathrm{x}$-oxalate complex, containing $1625 \mathrm{mmol}$ oxalate $\mathrm{kg}^{-1}$, as a function of $\mathrm{pH}(4.0-9.0)$. Oxalate was only partially removed in the absence of phosphate. Negligible amounts of oxalate were desorbed in the $\mathrm{pH}$ range 4.0-6.0, but greater quantities were removed at $\mathrm{pH}>7.0$, due to the presence of $\mathrm{OH}^{-}$ions. Phosphate replaced larger quantities of oxalate ions from the complex particularly in alkaline environments (oxalate desorbed $45 \%$ at $\mathrm{pH} 9.0$ ). The quantities of sulfate sorbed on the same complex were much lower than those of phosphate (data not shown; Violante et al., 2005), clearly because sulfate forms outer-sphere complexes in mildly acidic and alkaline environments and was not able to replace oxalate anions present in the organo-mineral complex.

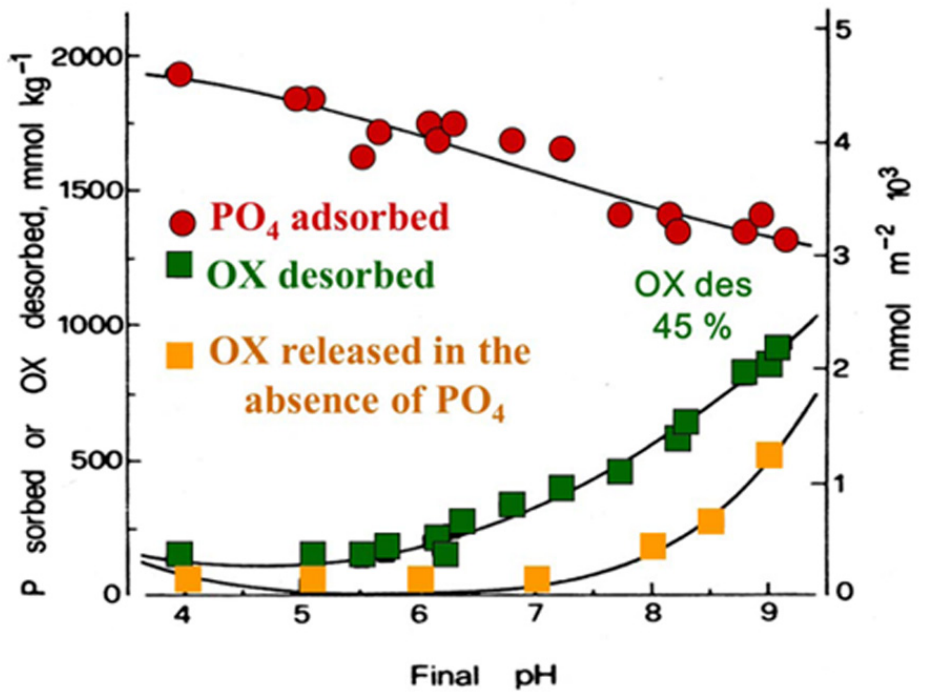

Figure 12. Effect of $\mathrm{pH}$ on the sorption of $2000 \mathrm{mmol} / \mathrm{kg}$ phosphate $\left(\mathrm{PO}_{4}\right)$ on an $\mathrm{Al}(\mathrm{OH}) \mathrm{x}$-oxalate complex, and desorption of oxalate (OX) from the complex in the presence or absence of phosphate (Modified from Violante et al., 1991).

In order to study the role of different LMMOLs present in synthetic organo-mineral complexes on the sorption of phosphate short-range ordered Aloxyhydroxides with comparable surface area (460-560 $\mathrm{m}^{2} \mathrm{~g}^{-1}$; Figure 13) were synthesized in the presence of critical concentrations of selected ligands (Violante and Huang, 1985; 1989); aspartate (L/Al molar ratio $[R]=0.2)$, citrate $(\mathrm{R}=0.01)$, tartrate $(\mathrm{R}=0.01)$, tannate $(\mathrm{R}=0.01$ and 0.02$)$. From 100 to $160 \mathrm{mmol}$ $\mathrm{kg}^{-1}$ of ligands were present in the poorly crystalline boehmites formed in the presence of citrate, tartrate, or tannate; a much greater amount of aspartate (437 mmol kg-1) was found in the sample formed in the presence of this ligand. The sample formed in the presence of aspartate retained more phosphate than the samples obtained in the presence of the other ligands, even though a much larger amount of organic anions was present in the former than in the latter. Clearly, aspartate which shows a moderate affinity for Al (Violante, 2013), would poorly counteract 
phosphate sorption and would be easily replaced by phosphate. On the other hand, citrate, tartrate, and tannate, which have a high affinity for Al, would not easily be removed and inhibit phosphate sorption. The amount of phosphate adsorbed by the precipitates after oxidation treatment $(\mathrm{NaOCl})$ strongly increased due to the removal of counteracting organic anions as well as disgregation of aggregates promoted by organic ligands. These findings demonstrate that phosphate sorption on organomineral complexes varied with the nature and amount of biomolecules present in the coprecipitates.

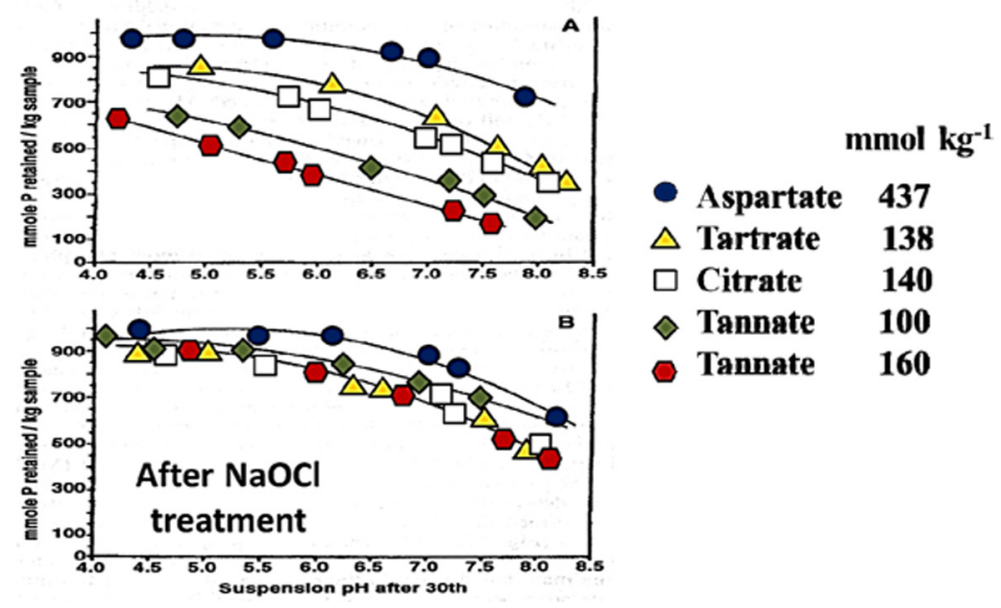

Figure 13. Sorption of phosphate by precipitation products of $\mathrm{Al}$ formed in the presence of organic ligands (A) before oxidation by $\mathrm{NaOCl}$ treatment and (B) after $\mathrm{NaOCl}$ treatment. In the Figure $\mathrm{A}$ are reported the amount of each organic anion which promoted the formation of poorly crystalline Al-oxyhydroxides (pseudo-boehmites) (Modified from Violante and Huang, 1989).

Martin et. al. (2009) demonstrated that arsenite and arsenate equilibria and the kinetics of arsenite sorption on ferrihydrite-coated kaolinite as influenced by the presence of organic matter coverage. The hampering effect of the organic matter on arsenic sorption was attributable to the blocking by the organic ligand of the adsorbing sites, coupled with the steric hindrance of the large organic molecules, which restricted the arsenic to approach the surfaces.

More recently, Zhu et al. (2010) studied the sorption of cations $[\mathrm{Pb}, \mathrm{Cu}$ and $\mathrm{Cr}(\mathrm{III})]$ added alone, in binary and ternary systems on an Fe-oxide (ferrihydrite) and on organomineral complexes obtained by coprecipitating $\mathrm{Fe}$ with equimolar amounts of oxalate and tartrate (tartrate + oxalate/Fe molar ratio of 0.1 or 0.2 ). Ferrihydrite sorbed much larger amounts of $\mathrm{Cu}, \mathrm{Cr}$ and $\mathrm{Pb}$ than the organomineral complexes when $\mathrm{mmol} / \mathrm{kg}$ mass scale was considered, owing to the larger surface area of ferrihydrite, whereas the opposite trend was true when $\mathrm{mmol} / \mathrm{m}^{2}$ surface scale was taken into account. Higher organic carbon content in the precipitates induced larger sorption $\left(\mathrm{mmol} / \mathrm{m}^{2}\right)$ of heavy metals. Moreover, heavy metals were sorbed more strongly on organomineral complexes than that on ferrihydrite because the presence of organic ligands provided strong complexing sites and decreased the point of zero charge (PZC) of the sorbents. The competition in sorption of the heavy metals was affected by the nature and the initial concentration of 
the elements, the surface properties of the sorbents, the addition sequence of the trace elements and the residence time. In binary systems the highest inhibition capacity on all the sorbents was for $\mathrm{Pb}$ versus $\mathrm{Cu}$, whereas the lowest was for $\mathrm{Cu}$ versus $\mathrm{Pb}$. The inhibition of $\mathrm{Cr}$ for $\mathrm{Cu}$ was much stronger than $\mathrm{Cu}$ for $\mathrm{Cr}$. However, $\mathrm{Cu}$ competed with $\mathrm{Cr}$ and $\mathrm{Pb}$ more intensely on the organomineral complexes than on ferrihydrite, whereas $\mathrm{Pb}$ competed with $\mathrm{Cr}$ more intensely onto ferrihydrite. In ternary systems, when equimolar amounts of each metal were added, the surface of the sorbents were covered with more than $50 \%$ by $\mathrm{Pb}$ (from 53 to $56 \%$ ), with 32 to $36 \%$ by $\mathrm{Cr}$ and with 9 to $13 \%$ by $\mathrm{Cu}$. However, even large amounts of $\mathrm{Pb}$ and/or $\mathrm{Cr}$ did not completely prevent the sorption of $\mathrm{Cu}$, clearly because some sites on the sorbents had a high affinity for this metal. Only when the concentration of $\mathrm{Cr}$ was much higher than that of $\mathrm{Pb}$, more sorption sites were occupied by $\mathrm{Cr}$ against $\mathrm{Pb}$ in binary and ternary systems.

The competitive sorption and desorption of $\mathrm{Cu}$ and $\mathrm{Cr}$ on/from goethite and goethite- $B$. thuringiensis complex was investigated by Zhu et al. (2012). Sorption isotherms and kinetics showed that the sorption of heavy metals was more and faster on goethite- $B$. thuringiensis complex than that on goethite and was suppressed by their competition. The competitive sorption between $\mathrm{Cu}$ and $\mathrm{Cr}$ was more intensive on goethite- $B$. thuringiensis complex than that on goethite and the competitive ability of $\mathrm{Cr}$ was stronger than that of $\mathrm{Cu}$ on both sorbents. Desorption observation of sorbed metals by $\mathrm{Ca}\left(\mathrm{NO}_{3}\right)_{2}$ showed that the desorption ratio of each metal was usually slightly higher from single system than that from binary systems. Lower desorption ratio of sorbed metal from goethite whereas relative higher desorption percentage from goethite- $B$. thuringiensis complex confirmed higher affinity of heavy metals for the former sorbent than that for the latter one.

\subsection{Effect of rhizosphere-competent beneficial fungi on the mobility of nutrients and metal(loid)s in the soil and their uptake by plants}

The mobility of nutrients and pollutants in the rhizosphere is affected by biogeochemical and biological processes. The interaction among soil components. microorganisms, fertilizers play a great role on the uptake by plants of nutrients and pollutants (Hinsinger et al., 2011).

For example, in the last years, our research group has carried out pot studies on the influence of rhizospherecompetent beneficial fungi [i,e., Arbuscular Mycorrhizal Fungi (AMF) and Trichoderma spp.] on the growth, arsenic uptake and partition inside tissues of edible plants (i.e., lettuce and escarole) or perennial grass (Chrysopogon zizanioides L.), grown either in an Italian As-contaminated soil (containing $250 \mathrm{mg}$ As $\mathrm{kg}^{-1}$ ) or irrigated with As-contaminated waters (from 0 to $37.5 \mathrm{mg} \mathrm{As} \mathrm{1}^{-1}$ ) (Caporale et al., 2014a; 2014b; Cozzolino et al., 2010; Pigna et al., 2014). Our results evidenced that plant inoculation with AMF or Trichoderma spp. alleviated the phytotoxic effect of arsenic, essentially by stimulating plant growth (Figure 14) and promoting phosphate uptake, with a consequent dilution of arsenic inside plant tissues. A lower translocation of the toxicant from roots to shoots and edible leaves of the inoculatedplants (with a positive outcome on yield and food quality) was also observed. The higher tolerance of AMF or Trichoderma-inoculated plants may be attributed, at least in part, to the loss of function of the direct phosphate uptake pathway (high-affinity phosphate transporters, by which arsenic is also taken up by plants), and the contemporary activation of mycorrhizal or Trichoderma phosphate transporters, able to transfer more selectively phosphate than arsenic ions from rhizosphere to plant roots. In the 
study of Cozzolino et al. (2010), indeed, we verified that the supply of moderate dose of a phosphatebased fertilizer to the AMF-inoculated lettuce plants produced the best outcomes, in term of plant growth, food quality and tolerance to As in the soil (Figure 14).

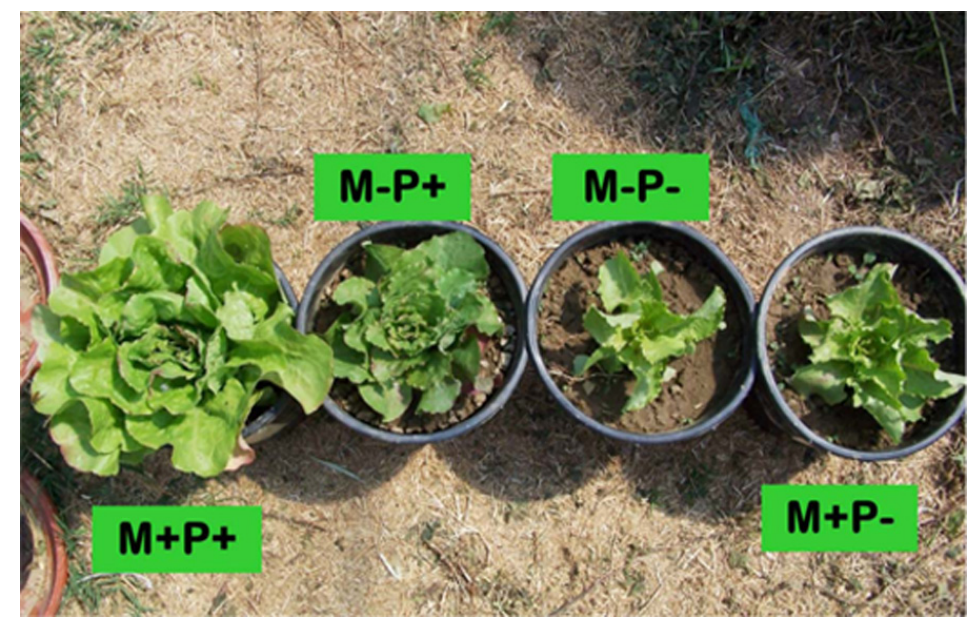

Figure 14. Production of biomass of lettuce plants (Lactuca sativa L.) grown on an Italian As-contaminated soil (250 mg As $\mathrm{kg}^{-1}$ ). M+ and M- indicates, respectively, AMF-inoculated and AMF-non-inoculated plants; $\mathrm{P}+$ and $\mathrm{P}$ - indicates, respectively, P-fertilized and P-non-fertilized plants.

By these pot studies, we also noted that the presence of AMF and Trichoderma spp. in the rhizospheric soil enhanced selectively the phytoavailability of phosphate vs. that of arsenic, although these elements are chemical analogues. Therefore, these scientific works indicate that plants inoculation with beneficial fungi may be helpful, beside the well-known positive effects, in alleviating the phytotoxicity of arsenic.

\subsection{Effect of root exudates on the sorption of biopolymers}

The possible effect of root exudates on the sorption of biopolymers have received some attention. Huang et al. (2005) demonstrated that citrate drastically inhibited the sorption of phosphatase on goethite, kaolinite and clay fractions of Chinese soils, clearly because citrate anions were able to form strong inner-sphere complexes on the surfaces of the sorbents and competed with the enzymatic molecules for sorption sites. With an increase in citrate concentrations sorption of enzyme decreased steadily (Figure 15). Conversely, acetate, which is weakly adsorbed on the surfaces of minerals and oxides, exerted no influence on enzyme fixation. These studies demonstrate that the presence of root exudates at the soil-plant interface may strongly influence the residual activity of enzymes by affecting their sorption onto soil components and organo-mineral complexes. 


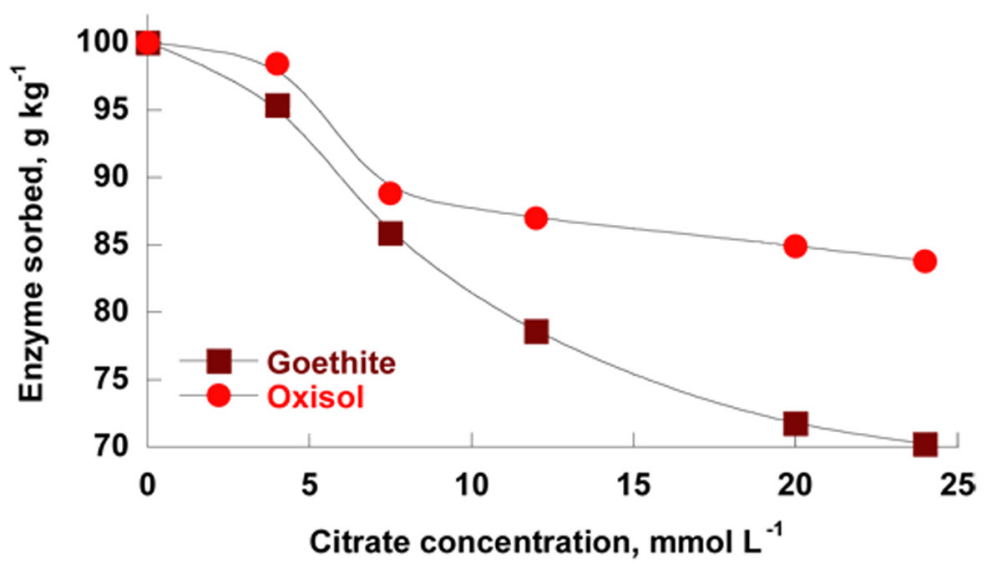

Figure 15. Amounts (\%) of acid phosphatase sorbed on Oxisol clay and goethite (kept in suspension) in the presence of increasing concentrations of citrate (Modified from Huang et al., 2005).

\section{Concluding remarks}

Biomolecules produced by plants and microorganisms are involved in the weathering of minerals and subsequent release of $\mathrm{Fe}, \mathrm{Al}$, and other cations promoting the formation of $\mathrm{Al}$ and $\mathrm{Fe}$ precipitation products (iron plaques) and organomineral complexes. They perturb the hydrolytic reactions of $\mathrm{Al}$ and $\mathrm{Fe}$ and influence the crystallization, mineralogy, surface properties and reactivity of their final precipitation products. The coprecipitation of root exudates and $\mathrm{Al}$ and/or Fe facilitate the formation of short-range ordered or noncrystalline oxides of extremely small size (nanomaterials). Low molecular mass organic ligands and biopolymers (e.g. enzymes) interact with clay minerals, humic substances, $\mathrm{OH}-\mathrm{Al}$ and $\mathrm{OH}-\mathrm{Fe}$ species, and/or microorganisms, promoting the formation of organo-mineral complexes with peculiar surface properties, reactivity and activity (if enzymes are present). The close association of organic substances with short-range ordered $\mathrm{Al}-$ and $\mathrm{Fe}$ - oxides and phyllosilicates strongly stabilize organic $\mathrm{C}$ in soil environments including rhizosphere. Finally, root exudates influence the sorption and desorption of nutrients and toxic elements on/from abiotic and biotic soil components and organo-mineral complexes. They also affect the mobility and bioavailability of nutrients and pollutants and the toxicity of metals and metalloids.

\section{Acknowledgments}

This work was supported by the Italian Research Program of National Interest (PRIN), year 2010-2011 (Grant number 2010JBNL17_005).

\section{References}

Alcacio, T.E., Hesterberg, D., Chou, J.W., Martin, J.D., Beauchemin, S., Sayers, D.E. 2001. Molecular scale characteristics of $\mathrm{Cu}(\mathrm{II})$ bonding in goethite-humate complexes. Geochim. Cosmochim. Acta. 65, 1355-1366. 
Barrow, N.J., Cartes, P., Mora, M. 2005. Modification to the Freundlich equation to describe anion sorption over a large range and to describe competition between pairs of ions. J. Soil Sci. 56, 601-606.

Borda, M.J., Sparks, D.L. 2008. Mobility of trace elements in soil environments. In: A. Violante, P.M. Huang, G.M. Gadd (eds). BiophysicoChemical Processes of Metals and Metalloids in Soil Environments. John Wiley \& Sons, Hoboken, NJ, pp. 97-168.

Buondonno, A., Felleca, D., Violante, A. 1989. Properties of organo-mineral complexes formed by different addition sequences of hydroxy-Al, montmorillonite and tannic acid. Clays Clay Miner. 37, 235-242.

Buondonno, A., Violante, A. 1991. Titratable acidity of organo-mineral complexes as affected by mode of preparation, drying and stability of the aggregates. Can. J. Soil Sci. 71, 285-292.

Burns, R.G. 1986. Interaction of enzymes with soil mineral and organic colloids. In: P.M. Huang, M. Schnitzer (eds). Interactions of soil minerals with natural organics and microbes. Soil Science Society of America, Madison, WI, pp. 429-451.

Caporale, A.G., Pigna, M., Dynes, J.J., Cozzolino, V., Zhu, J., Violante, A. 2011. Effect of inorganic and organic ligands on the sorption/desorption of arsenate on/from Al-Mg and Fe-Mg layered double hydroxides. J. Hazard. Mater. 198, 291298.

Caporale, A.G., Pigna, M., Azam, S.M.G.G., Sommella, A., Rao, M.A., Violante, A. 2013. Effect of competing ligands on the sorption/ desorption of arsenite on/from $\mathrm{Mg}$-Fe layered double hydroxides (Mg-Fe-LDH). Chem. Eng. J. 225, 704-709.
Caporale, A.G., Sarkar, D., Datta, R., Punamiya, P., Violante, A. 2014a. Effect of arbuscular mycorrhizal fungi (Glomus spp.) on growth and arsenic uptake of vetiver grass (Chrysopogon zizanioides L.) from contaminated soil and water systems. J. Soil Sci. Plant Nutr. 14, 955-972.

Caporale, A.G., Sommella, A., Lorito, M., Lombardi, N., Azam, S.M.G.G., Pigna, M., Ruocco, M. 2014b. Trichoderma spp. alleviate phytotoxicity in lettuce plants (Lactuca sativa L.) irrigated with arsenic-contaminated water. J. Plant Phys. 171, 1378-1384.

Chenu, C., Stotzky, G. 2002. Interaction between microorganisms and soil particles: an overview. In: P.M. Huang, J.M. Bollag, N. Senesi (eds). Interactions Between Soil Particles and Microorganism: Impact on the Terrestrial Ecosystem. John Wiley \& Sons, New York, NY, pp. 3-40.

Colombo, C., Ricciardella, M., Di Cerce, A., Maiuro, L., Violante, A. 2005. Effect of tannate, pH, sample preparation, aging, and temperature on the formation and nature of Al-oxyhydroxides. Clays Clay Miner. 52, 721-733.

Cozzolino, V., Pigna, M., Di Meo, V., Caporale, A.G., Violante, A. 2010. Effects of arbuscular mycorrhizal inoculation and phosphorus supply on the growth of Lactuca sativa L. and arsenic and phosphorus availability in an arsenic polluted soil under non-sterile conditions. Appl. Soil Ecol. $45,262-268$.

De Cristofaro, A., He, J.Z., Zhou, D.H., Violante, A. 2000. Adsorption of phosphate and tartrate on aluminum-oxalate precipitates. Soil Sci. Soc. Am. J. $64,1347-1355$.

De Cristofaro, A., Violante, A. 2001. Effect of hydroxy-aluminum species on the adsorption and interlayering of proteic molecules onto montmorillonite. App. Clay Sci. 19, 59-67. 
Ehrlich, H.L. 2002. Geomicrobiology. Marcel Dekker, New York, 768p.

Eusterhues, K., Rennert, T., Knicker, H., KogelKnabner, I, Totsche, K., Schwertmann, U. 2011. Fractionation of organic matter due to reaction with ferrihydrite: coprecipitation versus adsorption. Environ. Sci. Technol. 45 527-533.

Gadd, J.M. 2008. Transformation and mobilization of metals, metalloids, and radionuclides by microorganisms. In: A. Violante, P.M. Huang, G.M. Gadd (eds). Biophysico-chemical processes of metals and metalloids in soil environments. Wiley-JUPAC series. John Wiley \& Sons, Hoboken, NJ, vol. 1, pp. 53-96.

Gianfreda, L., Bollag, J.M. 1996. Influence of natural and anthropogenic factors on enzyme activity in soil. In: G. Stotzky, J.M. Bollag (eds). Soil biochemistry. Marcel Dekker, New York, NY, vol. 9, pp. 123-194.

Gianfreda, L., Rao, M.A., Mora, M. 2011. Enzymatic activity as influenced by soil mineral and humic colloids and its impact on biogeochemical processes. In: P.M. Huang, Y. Li, M.E. Summer (eds). Handbook of Soil Science Resource of Management and Environmental Impacts, Second Edition, CRC Press, Taylor \& Francis, chapt. 5, pp. 1-24.

He, J.Z., De Cristofaro, A., Violante, A. 1999. Comparison of adsorption of phosphate, tartrate and oxalate on hydroxy aluminum montmorillonite complexes. Clays Clay Miner.47, 226-233.

Hepistall, S.E., Turner, B.F., Maurice, P.A. 2005. Effects of siderophores on $\mathrm{Pb}$ and $\mathrm{Cd}$ adsorption to kaolinite. Clays Clay Miner. 53, 557-563.

Hinsinger, P. 1998. How do plant roots acquire mineral nutrients? Chemical processes involved in the rhizosphere. Adv. Agron. 64, 225-265.
Hinsinger, P. 2011. Biogeochemical, biophysical, and biological processes in the rhizosphere. In: P.M. Huang, Y. Li, M.E. Summer (eds). Handbook of Soil Science Resource of Management and Environmental Impacts, Second Edition, CRC Press, Taylor \& Francis, chapt. 6, pp. 1-30.

Huang, P.M., Violante, A. 1986. Influence of organic acids on crystallization and surface properties of precipitation products of aluminum. In: P.M. Huang, M. Schnitzer (eds). Interactions of soil minerals with natural organics and microbes. Special Publication n. 17, Soil Sci. Soc. Am, Madison, WI, pp. 159-221.

Huang, P.M., Germida, J.J. 2002. Chemical and biochemical processes in the rhizosphere: metal pollutants. In: P.M. Huang, J.M. Bollag, N. Senesi (eds). Interactions between Soil Particles and Microorganisms: Impact on the Terrestrial Ecosystem. John Wiley \& Sons, New York, NY, pp. 381-438.

Huang, Q., Pigna, M., Rao, M.A., Violante, A. 2005. Influence of acetate, phosphate and citrate on the adsorption of acid phosphatase on variable charge minerals and soil clays. In: P.M. Huang, J.M. Bollag, A. Violante, P. Vityakon (eds). Soil abiotic \& biotic interactions and the impact on the ecosystem \&human welfare. Science Publishers, Enfield, NH, pp. 409-426.

Jara, A., Violante, A., Pigna, M., De La Luz Mora, M. 2006. Mutual interactions of sulfate, oxalate, citrate and phosphate on synthetic and natural allophanes. Soil Sci. Soc. Am. J. 70, 337-346.

Kampf, N., Scheinost, A.C., Schultze, D.G. 2000. Oxide minerals. In: M.E. Sumner (ed). Handbook of Soil Science, CRC Press, Boca Raton, FL, pp. F125-F168. 
Kögel-Knaber, I., Guggenberger, G., Kleber, M., Kandeler, M., Kalbitz, K., Scheu, S., Eusterhues, K., Leinweber, P. 2008. Organo-mineral associations in temperate soils: integrating biology, mineralogy and organic matter chemistry. J. Plant Nutr. Soil Sci. 171, 61-82.

Liu, X., Eusterhues, K., Thieme, J., Ciobota, V., Höschen, C., Mueller, C.W., Küsel, K., KögelKnabner, I., Rösch, P., Popp, J., Totsche, K.U. 2013. STXM and NanoSIMS investigations on EPS fractions before and after adsorption to goethite. Environ. Sci. Technol. 47, 3158-3166.

Liu, F., He, J.Z., Colombo, C., Violante, A. 1999. Competitive adsorption of sulfate and oxalate on goethite in the absence or presence of phosphate. Soil Sci.164, 180-189.

Martin, M., Celi, L., Barberis, E., Violante, A., Kozak, L.M., Huang, P.M. 2009. Effect of humic acid coating on arsenic adsorption on ferrihydritekaolinite mixed systems. Can. J. Soil Sci. 89, 421434.

Martinez, C.E., Kleinschmidt, A.W., Tabatabai, M.A., 1998. Sulfate adsorption by variable charge soils: effect of low-molecular-weight organic acids. Biol. Fertil. Soils. 26, 157-163.

Neubauer, U., Nowak, B., Furrer, G., Schulin, R., 2000. Heavy metal sorption on clay minerals affected by the siderophore desferrioxamine B. Environ. Sci. Technol. 34, 2749-2755.

Neubauer, U., Furrer, G., Schulin, R. 2002. Heavy metal sorption on soil minerals affected by the siderophore desferrioxamine B: the role of Fe(III) (hydr)oxides and dissolve Fe(III). Eur. J. Soil Sci. 53, 45-55.

Pigna, M., Jara, A., Mora, M., Violante, A. 2007. Factors affecting the sorption of sulfate on Andisols. J. Soil Sci. Plant Nutr. 7, 162-173.
Pigna, M., Caporale, A.G., Cartes, P., Cozzolino, V., Mora, M., Sommella, A., Violante, A. 2014. Effects of arbuscular mycorrhizal inoculation and phosphorus fertilization on the growth of escarole (Cichorium endivia L.) in an arsenic polluted soil. J. Soil Sci. Plant Nutr. 14, 199-209.

Pinton, R., Varanini, Z., Nannipieri, P. 2001. The rhizosphere: biochemistry and organic substances at the soil-plant interface. M. Dekker Inc., New York, NY, p. 424.

Robert, M., Berthelin, J. 1985. Interactions of soil minerals with natural organics and microbes. In: P.M. Huang, M. Schnitzer (eds). Soil Sci. Soc. Am., Special Publication n. 17, Madison, WI, pp. 453-495.

Seguin, V., Courchesne, F., Gagnon, C., Martin, R.R., Naftel, S.J., Skinner, W. 2005. Mineral weathering in the rhizosphere of forested soils. In: P.M. Huang, G.R. Gobran (eds). Biogeochemistry of Trace Elements in the Rhizosphere. Elsevier, Amsterdam, The Netherlands, pp. 29-55.

Shirvani, M., Shariatmadari, H., Kalbasi, M., Nourbakhsh, F., Najafi, B. 2006. Sorption of cadmium on palygorskite, sepiolite and calcite: equilibria and organic ligand affected kinetics. Colloids Surf. A: Physicochem. Eng. Aspects. 287, 182-190.

Sparks, D.L. 2002. Environmental Soil Chemistry, Second Edition. Academic Press, San Diego, CA, $368 \mathrm{p}$.

Theng, B.K.G. 1979. Formation and properties of clay-polymer complexes. Elsevier, Amsterdam, the Netherlands, p. 362.

Vance, G.F., Stevenson, F.J., Sikora F.J. 1996. Environmental chemistry of aluminum-organic complexes. In: G. Sposito (ed). The environmental chemistry of aluminium. CRC, Boca Raton, FL, pp. 169-220. 
Violante, A., Huang, P.M. 1985. Influence of inorganic and organic ligands on precipitation products of aluminum. Clays Clay Miner. 33, 181-192.

Violante, A., Huang, P.M. 1989. Influence of oxidation treatments on surface properties and reactivities of short range ordered products of aluminum. Soil Sci. Soc. Am. J. 53, 1402-1407.

Violante, A., Colombo, C., Buondonno, A. 1991. Competitive adsorption of phosphate and oxalate on Al-oxides. Soil Sci. Soc. Am. J. 55, 65-70.

Violante, A., Gianfreda, L., Violante, P. 1993. Effect of prolonged aging on the transformation of short-range ordered aluminum precipitation products formed in the presence of organic and inorganic ligands. Clays Clay Minerals. 41, 353359.

Violante A., Gianfreda, L. 1995. Adsorption of phosphate on variable charge minerals: competitive effect of organic ligands. In: P.M. Huang, J.M. Bollan, W.B. McGill, A.L. Page (eds). Environmental Impact of Soil Component Interactions. CRC Lewis Publ., London, UK, vol. 2, chapt. 3, pp. 29-38.

Violante, A., Arienzo, M., Sannino, F., Colombo, C., Piccolo, A., Gianfreda, L. 1999. Formation and characterization of OH-Al-humatemontmorillonite complexes. Organ. Geochem. $30,461-468$.

Violante A., Gianfreda L. 2000. Role of biomolecules in the formation and reactivity towards nutrients and organics of variable charge minerals and organo-mineral complexes in soil environment, from soil biochemistry. In: J.M. Bollag, G. Stotsky (eds). Marcel \& Dekker, New York, chapt. 4, pp. 207-270.
Violante, A., Krishnamurti, G.S.R., Huang, P.M. 2002 Impact of organic substances on the formation of metal oxides in soil environments. In: P.M. Huang, J.M. Bollag, N. Senesi (eds). Interactions between soil particles and microorganism: impact on the terrestrial ecosystem. John Wiley \& Sons, New York, NY, pp. 133-188.

Violante, A., Barberis, E., Pigna, M., Boero, V. 2003. Factors affecting the formation, nature and properties of iron precipitation products at the soil-root interface. J. Plant Nutr. 26, 1889-1908.

Violante, A., Pigna, M., Liu, F. 2005.Sorption/ desorption of sulfate on/from variable charge minerals and soils: competitive effects of organic and inorganic ligands. In: P.M. Huang, J.M. Bollag, A. Violante, P. Vityakon (eds). Soil Abiotic \& Biotic Interactions and the Impact on the Ecosystem \&Human Welfare. Science Publishers, Enfield, NH, pp. 195-221.

Violante, A., Krishnamurti, G.S.R., Pigna, M. 2008. Mobility of trace elements in soil environments. In: A. Violante, P.M. Huang, G. Gadd (eds). Biophysico-chemical processes of metals and metalloids in soil environments. John Wiley \& Sons, Hoboken, NJ, pp. 168-213.

Violante, A., Pigna, M., Cozzolino, V., Huang, P.M. 2011. Impact of soil physical, chemical and biological interactions on the transformation of metals and metalloids. In: P.M. Huang, Y. Li, M.E. Summer (eds.) Handbook of Soil Science Resource of Management and Environmental Impacts, Second Edition. CRC Press, Taylor \& Francis, chapt. 8, pp. 1-29.

Violante A. 2013. Elucidating mechanisms of competitive sorption at the mineral/water interface. In: D.L. Sparks (ed). Adv. Agron. 118, 111-176. 
Violante, A., Zhu, J., Pigna, M., Jara, A., Cozzolino, V., Mora, M.L. 2013. Role of biomolecules in influencing transformation mechanisms of metals and metalloids in soils. In: J. Xu, D.L. Sparks (eds). Springer, Chapt. 6, 167-191.

$\mathrm{Xu}, \mathrm{B}$., Yu, S. 2013. Root iron plaque formation and characteristics under $\mathrm{N}_{2}$ flushing and its effects on translocation of $\mathrm{Zn}$ and $\mathrm{Cd}$ in paddy rice seedlings (Oryza sativa). Annales Botany. 111, 1189-1195.

Wu, Z., Gu, Z., Wang, X., Evans, L., Guo, H., 2003. Effects of organic acids on adsorption of lead onto montmorillonite, goethite and humic acid. Environ. Pollut. 121, 469-475.

Yuan, G., Theng, B.K.G. 2011. Clay-organic interactions in soil environments.In: P.M. Huang, Y. Li, M.E. Summer (eds). Handbook of Soil Science Resource of Management and Environmental Impacts, Second Edition. CRC Press, Taylor \& Francis, chapt. 2, pp. 1-20.
Zhu, J., Pigna, M., Cozzolino, V., Caporale, A.G., Violante, A. 2010. Competitive sorption of copper(II), chromium(III) and lead(II) on ferrihydrite and two organomineral complexes. Geoderma. 159, 409-416.

Zhu, J., Huang, Q., Pigna, M., Violante, A. 2012. Competitive sorption of $\mathrm{Cu}$ and $\mathrm{Cr}$ on goethite and goethite-bacteria complex. Chem. Eng. J. 179, 26-32.

Zhu, J., Pigna, M., Cozzolino, V., Caporale, A.G., Violante, A. 2011. Sorption of arsenite and arsenate on ferrihydrite: Effect of organic and inorganic ligands. J. Hazard. Mat. 189, 564-571.

Zhu, J., Pigna, M., Cozzolino, V., Caporale, A.G., Violante, A. 2013. Higher sorption of arsenate versus arsenite on amorphous Al-oxide, effect of ligands. Environ. Chem. Lett. 11, 289-294. 